\title{
ANALISIS FAKTOR-FAKTOR YANG MEMPENGARUHI NASABAH DALAM MENGGUNAKAN PRODUK JASA PERBANKAN SYARIAH (STUDI PT BANK NEGARA INDONESIA CABANG SUKABUMI)
}

\section{ANALYSIS OF FACTORS INFLUENCING THE CUSTOMER IN PRODUCT USING ISLAMIC BANKING SERVICES (STUDY PT BANK NEGARA INDONESIA SUKABUMI BRANCH)}

\author{
Ridwan Arif Setiawan'1a Sahlan Hasbi2b \\ 1aProgram Studi Ekonomi Islam Fakultas Ekonomi Islam Universitas Djuanda Bogor, Jl. \\ Tol Ciawi No. 1, Kode Pos 35 Bogor 16720 \\ ${ }^{2 b}$ Program Studi Perbankan Syariah Fakultas Ekonomi Islam Universitas Djuanda Bogor, \\ Jl. Tol Ciawi No. 1, Kode Pos 35 Bogor 16720
}

E-mail : ridwan.arif.setiawan@unida.ac.id, sahlan.hasbi@unida.ac.id

(Diterima oleh Dewan Redaksi: 22-01-2016)

(Dipublikasikan oleh Dewan Redaksi:01-06-2016)

\begin{abstract}
This study aims to determine the factors that influence the customer in using the product and services of Islamic banking studies at PT Bank Negara Indonesia Sukabumi branch. The number of respondents in this study many 202 by using convenience sampling technique. The method used is the method of factor analysis obtained figures Kaiser Meyer Olkin Measure Of Sampling Adequacy ( KMO - MSA ) of 0,748. Hal this is good because it is above 0.5. The value of Barlett 's Test of Sphericity 748,018dengan significant value of 0.000 . This means that the value of the variable form factor is good and can be analyzed further. Results of the analysis of the data obtained showed that four variables: the facilities, service, religion, promotion. Religious factors strongly influence the customer's decision to use the products of Islamic banking services because it has a higher value on the main factor.
\end{abstract}

Keywords : Analysis, factors, customers, Islamic banking

\section{ABSTRAK}

Penelitian ini bertujuan untuk mengetahui faktor-faktor yang mempengaruhi nasabah dalam menggunakan produk jasa perbankan syariah studi pada PT Bank Negara Indonesia cabang Sukabumi. Jumlah responden pada penelitian ini banyak 202 dengan menggunakan teknik convenience sampling. Metode yang digunakan adalah metode analisis faktor diperoleh angka Kaiser Meyer Olkin Measure of Sampling Adequacy (KMO-MSA) sebesar 0,748. Hal ini sudah baik karena sudah di atas 0,5. Nilai Barlett's Test of Sphericity 748,018 dengan nilai signifikan 0,000. Nilai ini berarti bahwa faktor pembentuk variabel sudah baik dan dapat dianalisis lebih lanjut.Hasil analisis data yang diperoleh dapat diketahui bahwa 4 variabel yaitu fasilitas, pelayanan, agama, promosi. Faktor agama sangat mempengaruhi keputusan nasabah dalam menggunakan produk jasa perbankan syariah karena memiliki nilai lebih tinggi pada faktor utama. 
Setiawan, Ridwan Arif. 2016. Analisis Faktor-Faktor Yang Mempengaruhi Nasabah Dalam Menggunakan Produk Jasa Perbankan Syariah (Studi PT Bank Negara Indonesia Cabang Sukabumi. (6) : 221-236

\section{PENDAHULUAN}

Lembagaperbankan merupakan salah satu lembaga terpenting dalam sistem perekonomian modern. Tidak ada satupun negara modern yang menjalankan kegiatan perekonomianya tanpa melibatkan lembaga perbankan (Muhammad, 2008:17). Perbankan merupakan sebuah lembaga intermediasi yang berfungsi sebagai penghubung (intermediator) antara surplus unit dengan defisit unit, dengan cara menghimpun dana yang berasal dari masyarakat dalam bentuk tabungan maupun deposito dan kemudian disalurkan kembali kepada masyarakat dalam bentuk kredit atau pembiayaan.

Pembiayaan merupakan salah satu usaha perbankan untuk memperoleh pendapatannya. Pada bank syariah pendapatan ini bisa berupa bagi hasil atau jika dalam perbankan konvensional dikenal dengan istilah bunga. Namun usaha perbankan dibidang pembiayaan ini mengandung suatu unsur risiko menurunnya produktifitas atas usaha yang dilakukan oleh nasabah yang dibiayai olehbank, dan dapat menyebabkan non performing financing sehingga berpengaruh terhadap pendapatan yang akan diterima oleh deposan. Seiring dengan perkembangan zaman dan banyaknya pembukaan kantor cabang syariah, persaingan dalam industri perbankanpun kian meningkat, baik itu persaingan dibidang teknologi, nisbah bagi hasil, maupun persaingan dibidang lainnya. Sehingga bank harus mencari alternatif pendapatan lain selain hanya mengandalkan pendapatan dari kegiatan penyaluran kredit atau pembiayaan guna untuk mendapatkan keuntungan dan juga untuk memenuhi biaya operasional perusahaan untuk dapat bersaing dengan bank-bank lainnya, suatu bank dituntut untuk memberikan jasa yang berkualitas sehingga dapat memberikan kepuasankepada nasabah yang menggunakan jasa bank tersebut. Bank yang ingin berkembang harus menampilkan produk dan jasa yang lebih unggul dari bank lainnya. Semakin banyak nasabah yang menggunakan produk jasa suatu bank maka akan meningkatkan jumlah pendapatan dari bank tersebut. Pendapatanyang berasal dari pelayanan jasa bank ini disebut juga dengan fee based income.

Jasa bank yang diberikan kepada nasabah sangat penting dalam pembangunan ekonomi suatu negara. Tujuan pelayanan jasa bank adalah untuk mendukung dan memperlancar kegiatan transfer and payment yang dilakukan oleh nasabah. Selain itu, sebagai penyedia mekanisme dan alat pembayaran yang efisien bagi nasabah. Jasa yang diberikan perbankan kepada masyarakat dapat berupa jasa pengiriman uang (transfer), jasa penagihan, jasa pembayaran listrik, telepon, air, atau uang kuliah, jasa pembayaran seperti pembayaran gaji, kliring, penjualan mata uang asing, penyimpanan dokumen, jasa cek wisata, kartu kredit, dan jasa-jasa lainnya. Semakin lengkap jasa bank yang ditawarkan maka akan semakin baik, karena bank tersebut akan mampu melayani masyarakat atau nasabah dalam kegiatan transfer and payment dengan baik. Sehingga nasabah akan merasa nyaman dalam memilih dan menggunakan jasa bank tersebut. Semakin menjamurnya keberadaan bank saat ini, akan menjadikan persaingan antar bank semakin ketat, 
sehingga bank berlomba-lomba untuk mendapatkan dan meningkatkan jumlah nasabahnya.

Nasabah saat ini semakin selektif dalam menggunakan produk jasa suatu bank. Hal ini tentu saja akan semakin meningkatkan kompetisi di dunia perbankan di Indonesia. Bagi seorang nasabah keberadaan dan penggunaan produk jasa ini sangatlah penting dalam memperlancar kegiatan bisnis maupun kegiatan sehari-hari. Bank-bank tentu saja berlomba-lomba untuk memperbaiki diri dalam pelayanan perusahaannya. Bank yang ingin berkembang, atau paling tidak bertahan hidup dalam persaingan saat ini harus bisa mendapatkan dan meningkatkan jumlah nasabahnya. Oleh karena itu, bank harus mengetahui faktor-faktor yang mempengaruhi nasabahnya dalam memilih produk-produk yang ditawarkan oleh bank tersebut.

\section{MATERI DAN METODE}

\section{Tinjauan Teoritis}

1. Produk Perbankan Syariah

Dalam menjalankan kegiatan usahanya, perbankan syariah di Indonesia memiliki produk-produk yang mendukung kelancaran usaha perbankan tersebut. Menurut Karim (2006:97) produk dasar Perbankan Syariah yang biasa ditawarkan dapat dibagi menjadi tiga bagian besar, yaitu produk penghimpunan dana (funding), produk penyaluran dana (financing), danjasa. Pada institusi bank, jasa merupakan kegiatan yang sangat penting digalakan. Hal ini sejalan dengan UU no 21 tahun 2008 tentang perbankan Pasal 1 ayat 8, yakni bank umum syariah adalah bank syariah yang dalam operasional kegiatannya dapat memberikan jasa dalam lalu lintas pembayaran. Disamping itu, jasa perbankan juga memiliki implikasi meningkatkan
ROA (Return On Asset) dan ROE (Return On Equity) bank. Filosofinya adalah bank memperoleh tambahan pendapatan dari pelayanan bank. Akan tetapi,tidak akan menambah posisi aset. Karena returnnya naik sementara asset tetap maka ROA bank menjadi naik. Dalam kegiatan jasa ini bank mendapatkan keuntungan berupa fee (ujrah). Keuntungan dari kegiatan memberikan jasa dalam perbankan dinamakan fee base income. Pengertian fee based income adalahkeuntunganyangdidapatdaritr ansaksiyang diberikan dalam jasajasa bank lainnya atau selain spread based(Kasmir, 2001:109).

Dalam PSAK No. 31 BAB I huruf A angka 03 menjelaskan bahwa dalam operasionalnya bank melakukan penanaman dalam aktiva produktif seperti kredit dan surat-surat berharga juga memberikan komitmen dan jasa-jasa lain yang digolongkan sebagai "fee based operation", atau off balance sheet activities".

2. Keputusan Pembelian

Menurut Drumond (2003:68), keputusan pembelianadalah mengidentifikasikan semua pilihan yang dapat memecahkan permasalahan dan menilai pilihanpilihan secara sistematis dan obyektif serta sasaran-sasarannya yang menentukan keuntungan serta kerugiannya masing-masing. Definisi keputusan pembelian menurut Nugroho (2003:38) adalah proses pengintegrasian yang mengkombinasi sikap pengetahuan untuk mengevaluasi dua atau lebih perilaku alternatif, dan memilih salah satu diantaranya.Pengambilan keputusan merupakan suatu kegiatan seseorang yang secara langsung terlibat dalam 
mendapatkan dan mempergunakan barang yang ditawarkan.

3. Identifikasi Jenis-Jenis Nasabah Nasabah adalah semua individu yang menuntut suatu bank untuk memenuhi suatu standar kualitas tertentu, oleh karena itu maka akan memberikan pengaruh pada kinerja perbankan itu sendiri.Dalam sistem kualitas modern menurut Sipahutar (2002: 10), terdapat tiga jenis nasabah yang harus dipenuhi kebutuhannya, yaitu :

a) Nasabah Internal

Adalah orang yang berada dalam lingkup suatu bank dan memiliki pengaruh pada performa bank. Contohnya adalah bagian pembayaran, rekruitmen, karyawan.

b) Nasabah Antara

Adalah orang yang bertindak sebagai perantara suatu produk, bukan sebagai pemakai akhir suatu produk atau jasa.

c) Nasabah Eksternal

Adalah orang yang membayar untukmenggunakan produk dan jasa yang diperoleh dari suatu perusahaan

\section{Metode Penelitian}

1. Uji Validitas dan reliabilitas

Digunakan untuk mengetahui kelayakan butir-butir dalam suatu daftar pertanyaan. Validitas mengukur sejauh mana suatu alat ukur itu mengukur apa yang ingin anda ukur. Sehingga dapat dikatakan mampu memperoleh data yang tepat dari variable yang diteliti. Kriteria dari validitas yaitu bila koefisien kolerasi masing-masing pertanyaan dengan nilai Corrected Item Total Correlation lebih besar atau sama dengan $r$ tabel. Maka, instrument dinyatakan valid. Sedangkan reabilitas adalah suatu angka indeks yang menunjukan konsistensi suatu alat ukur dalam mengukur suatu gejala yang sama. Setiap alat ukur seharusnya memberikan hasil pengukuran yang konsisten (Husein, Umar, 2005: 135).

Suatu variabel dikatakan reliabel jika nilai cronbach alpha> 0,6 (Ghazali, 2001: 42).

Rumus cronbach alpha :

$$
\mathrm{r}_{11}\left(\begin{array}{l}
\mathrm{k}-1 \\
-1
\end{array}\right)\left(\begin{array}{l}
\mathrm{K} \sum S^{2}{ }_{b} \\
S_{t}{ }_{t}
\end{array}\right)
$$

Sumber : Husein, Umar, $2008: 170$

Keterangan:

$\mathrm{r}_{11} \quad$ : reliabilitas instrument

$\mathrm{k} \quad$ : banyak butir pertanyaan

$S^{2}{ }_{t} \quad$ : deviasi standar total

$\sum S{ }_{b}$ : jumah deviasi standar butir

\section{Analisis Faktor}

Teknik analisis data yang penulis gunakan adalah teknik analisis faktor. Analisis faktor adalah suatu teknik analisis statistik multivariate yang biasa digunakan untuk mengurangi dan meringkas setiap variabel terikat dan saling ketergantungan.Analisis faktor hampir mirip dengan regresi linier berganda yaitu setiap variabel dinyatakan sebagai suatu kombinasi linier darifaktor yang mendasari (underlying factors). Jumlah (amount) varian yang disumbangkan oleh suatu variabel dengan variabel lainya yang tercakup dalam analisis tersebut disebut communality. Kovariasi antar variabel yang diuraikan, dinyatakan dalam suatu common factors yang sedikit jumlahnya ditambah dengan faktor yang unik untuk setiap variabel (Supranto, 2004 : 144).

3. Uji Kaiser Mayer Olkin (KMO) KMO merupakan sebuah objek indeks perbandingan jarak antara koefisien korelasi versial secara keseluruhan. 
Jika jumlah kuadrad korelasi parsial di antara seluruh pasangan variabel bernilai kecil dibandingkan dengan jumlah kuadrad kofisien korelasi, maka akan menghasilkan nilai KMO yang mendekati satu. Nilai KMO yang kecil menunjukan bahwa analisi faktor bukan pilihan yang tepat. Untuk dapat analisis faktor, nilai KMO dianggap cukup apabila nilai KMO 0,5

\section{Populasi dan Sampel}

Populasi adalah wilayah generalisasi yang terdiri atas subjek atau objek yang memiliki kualitas dan karakteristik tertentu yang diterapkan oleh peneliti untuk dipelajari kemudian ditarik kesimpulan. Sedangkan sampel adalah suatu himpunan bagian (subset) dari unit populasi (Kuncoro, 2003:103).

Sampel penelitian adalah bagian dari populasi yang dijadikan subyek. Tekniksampling yang digunakan adalah teknik convenience sampling. convenience sampling adalah istilah umum yang mencakup variasi luasnyaprosedur pemilihan responden. Convenience sampling berarti unit sampel yang ditarik mudah dihubungi, tidak menyusahkan, mudah untuk mengukur, dan bersifat kooperatif. (Abdul Hamid, 2007:30).

\section{Objek dan Lokasi Penelitian}

Objek dari penelitian ini adalah PT Bank Negara Indoensia (BNI) Syariah cabang Sukabumi. Alamat Jl. A.Yani no. 29 -Kelurahan Gunung parangKecamatan Cikole - Sukabumi - 43113.

\section{Teknik Pengumpulan Data}

Dalam penelitian ini, metode pengumpulan data yang digunakan adalah:

\section{Angket Kuisioner}

Adalah suatu cara mengumpulkan data dengan memberikan daftar pertanyaan pada responden dengan harapan daftar pertanyaan tersebut dijawab oleh responden.Daftar pertanyaan yang diberikan bersifat tertutup, sehingga alternatifalternatif jawaban yang akan diberikan telah disediakan (Husein, Umar, 2002:14).

Kuisioner menggunakan skala likert, skala ini berhungungan dengan pertanyaan tentang sikap seseorang terhadap sesuatu, misalnya setujutidak setuju, senang-tidak senang, baik-tidak baik (Husein, Umar, 2005: 89).

Dengan rumusan sebagai berikut:

\section{Tabel 1 Skala Likert}

\begin{tabular}{cl} 
Bobot & \multicolumn{1}{c}{ Kategori } \\
\hline 5 & Sangat Setuju \\
4 & Setuju \\
3 & Ragu-ragu \\
2 & Tidak Setuju \\
1 & Sangat Tidak Setuju \\
\hline Sumber: Husein, Umar, 2005: 89
\end{tabular}

Dengan menggunakan skala likert 5 poin. Skala ini digunakan dengan cara memberikan daftar pertanyaan pada responden, dengan menjawab berdasarkan tingkatan jawaban yang tersedia. Mulai dari sangat setuju, setuju, ragu-ragu, tidak setuju, sangat tidak setuju.

2. Mengakses website/situs internet Metoda ini dilakukan dengan menelusuri website/situs yang menyediakan informasi yang berhubungan dengan penelitian ini.

\section{HASIL DAN PEMBAHASAN}

\section{Uji Validitas dan Reliabilitas}

\section{a) Uji Realiabilitas}

Uji realiabilitas dari masingmasing faktor menggunakan Cronbach's Alpha. Kuesioner dinyatakan reliabel jika nilai koefisien alpha lebih besar > 0,6. Hasil nilai keofisien ini dapat dilihat pada tabel berikut : 
1) Faktor fasilitas

Tabel 2.Reliability Statistics

\begin{tabular}{rc}
\hline Cronbach's Alpha & N of Items \\
83 & 5 \\
0 & \\
\hline
\end{tabular}

Sumber : Diolah dari hasil penelitian

Tabel 3.4di atas memiliki nilai Cronbach's Alpa sebesar 0,830 di atas 0,6 maka instrument dinyatakan reliabel.Hasil pengujian tersebut menyatakan bahwa semua instrument pertanyaan dinyatakan reliabel karena nilai koefisien Cronbach Alpha yang diperoleh lebih besar dari 0,6 (a >0,6).

2) Faktor agama

\begin{tabular}{ll} 
Tabel 3.Reliability Statistics \\
\hline Cronbach's Alpha & $\begin{array}{l}\mathrm{N} \\
\text { Items }\end{array}$ \\
,766 & 5
\end{tabular}

Sumber : Diolah dari hasil penelitian

Tabel 4.4di atas memiliki nilai Cronbach's Alpa sebesar 0,766 di atas 0,6 maka instrument dinyatakan reliabel. Dari hasil pengujian instrumen maka semua instrument dikatakan reliabel karena nilai koefisien Cronbach Alpha yang diperoleh lebih besar dari 0,6 $(a>0,5)$.

3) Faktor Promosi

Tabel 4. Reliability Statistics

Cronbach's Alpha N of Items

,710 4

Sumber : Diolah dari hasil penelitian

Tabel 5.4di atas memiliki nilai Cronbach's Alpa sebesar 0,710 di atas 0,6 maka instrument

a) Faktor Fasilitas dinyatakan reliabel. Dari hasil pengujian instrumen maka semua instrument dikatakan reliabel karena nilai koefisien Cronbach Alpha yang diperoleh lebih besar dari 0,6 (a >0,5).

4) Faktor Pelayanan

Tabel5. Reliability Statistics

$\begin{array}{cc}\text { Cronbach's Alpha } & \mathrm{N} \text { of } \\ \text { Items }\end{array}$

, 771

7

Sumber : Diolah dari hasil penelitian

Tabel 6.4di atas memiliki nilai Cronbach's Alpa sebesar 0,771 di atas 0,6 maka instrument dinyatakan reliabel. Dari hasil pengujian instrumen maka semua instrument dikatakan reliabel karena nilai koefisien Cronbach Alpha yang diperoleh lebih besar dari 0,6 (a>0,5).

b) Uji Validitas

Uji validitas dilakukan untukmenguji kuesioner layak untuk digunakan sebagai instrument penelitian. Validitas dalam penelitian ini menggunakan bantuan Software SPSS versi 20 for Windows untuk memperoleh hasil yang terarah.

Kriteria dari validitas yaitu bila koefisien kolerasi masing-masing pertanyaan dengan nilai Corrected Item Total Correlation lebih besar atau sama dengan $r$ tabel. Maka, instrument dinyatakan valid (nilai $r$ tabel dengan responden 30 orang adalah 0,361). Hasil uji validitas melalui program SPSS 20 diuraikan dalam tabel berikut: 
Tabel 6.Validitas Instrumen Penelitian

\begin{tabular}{lllll}
\hline & $\begin{array}{l}\text { Scale Mean if } \\
\text { Item Deleted }\end{array}$ & $\begin{array}{l}\text { Scale Variance if } \\
\text { Item Deleted }\end{array}$ & $\begin{array}{l}\text { Corrected Item- } \\
\text { Total Correlation }\end{array}$ & Keterangan \\
\hline FS1 & 17,6667 & 2,506 &, 742 & Valid \\
FS2 & 17,6000 & 2,317 &, 716 & Valid \\
FS3 & 17,5667 & 2,530 &, 672 & Valid \\
FS4 & 17,5333 & 2,740 &, 515 & Valid \\
\hline
\end{tabular}

Sumber : Diolah dari hasil penelitian

Dari hasil pengolahan data, dapat dikatakan 5 yang valid dengan skor total dilihat bahwa koefisien kolerasi dari $>0,361$ dan dapat diolah lebih lanjut.

5 butir pertanyaan pada faktor

budaya yang ada,

b) Faktor Agama

Tabel 7. Validitas Instrumen Penelitian

\begin{tabular}{lllll}
\hline & $\begin{array}{l}\text { Scale Mean if } \\
\text { Item Deleted }\end{array}$ & $\begin{array}{l}\text { Scale Variance } \\
\text { if Item Deleted }\end{array}$ & $\begin{array}{l}\text { Corrected Item- } \\
\text { Total Correlation }\end{array}$ & Keterangan \\
\hline AG5 & 17,4667 & 3,292 &, 621 & Valid \\
AG6 & 17,4667 & 3,292 &, 621 & Valid \\
AG7 & 17,8333 & 3,109 &, 490 & Valid \\
AG8 & 17,6000 & 3,490 &, 616 & Valid \\
\hline
\end{tabular}

Sumber : Diolah dari hasil penelitian

Dari hasil pengolahan data, dapat dikatakan 4 yang valid dengan skor total dilihat bahwa koefisien kolerasi dari $>0,361$ dan dapat diolah lebih lanjut.

4 butir pertanyaan pada faktor

sosial yang ada,

c) Faktor Promosi

Tabel 8. Validitas Instrumen Penelitian

\begin{tabular}{lllll}
\hline & $\begin{array}{l}\text { Scale Mean } \\
\text { if Item } \\
\text { Deleted }\end{array}$ & $\begin{array}{l}\text { Scale Variance } \\
\text { if Item Deleted }\end{array}$ & $\begin{array}{l}\text { Corrected Item- } \\
\text { Total Correlation }\end{array}$ & Keterangan \\
\hline Pr9 & 12,1333 & 2,120 &, 599 & Valid \\
Pr10 & 12,2667 & 2,616 &, 431 & Valid \\
Pr11 & 12,2000 & 1,683 &, 661 & Valid \\
\hline
\end{tabular}

Sumber : Diolah dari hasil penelitian

Dari hasil pengolahan data, dapat dikatakan 4 yang valid dengan skor total dilihat bahwa koefisien kolerasi dari $>0,361$ dan dapat diolah lebih lanjut.

4 butir pertanyaan pada faktor

sosial yang ada, 
Tabel 9. Validitas Instrumen Penelitian

\begin{tabular}{lllll}
\hline & $\begin{array}{l}\text { Scale Mean if } \\
\text { Item Deleted }\end{array}$ & $\begin{array}{l}\text { Scale Variance } \\
\text { if Item Deleted }\end{array}$ & $\begin{array}{l}\text { Corrected Item- } \\
\text { Total Correlation }\end{array}$ & Keterangan \\
\hline pl12 & 26,6000 & 4,869 &, 544 & Valid \\
Pl13 & 26,7000 & 4,769 &, 553 & Valid \\
Pl14 & 26,6000 & 5,145 &, 430 & Valid \\
Pl15 & 26,7667 & 4,875 &, 548 & Valid \\
Pl16 & 26,6000 & 5,076 &, 534 & Valid \\
Pl17 & 26,2333 & 5,633 &, 416 & Valid \\
Pl18 & 26,3000 & 5,528 &, 428 & Valid \\
\hline
\end{tabular}

Sumber : Diolah dari hasil penelitian

Dari hasil pengolahan data, dapat dilihat bahwa koefisien kolerasi dari 7 butir pertanyaan pada faktor sosial yang ada, dikatakan 7 yang valid dengan skor total > 0,361 dan dapat diolah lebih lanjut.

\section{AnalisisFaktor-Faktor Yang Mempengaruhi Nasabah Dalam Menggunakan Produk Jasa Perbankan Syariah}

Dalam penelitian ini menggunakan 18 pertanyaan pada kuesioner yang mengarahkan responden pada variabel mana yang mempengaruhinasabah dalam menggunakan produk jasa perbankan syariah.

Metode analisis data yang digunakan adalah metode analisis faktor dengan bantuan software SPSS Versi 20.0 for windows. Untuk lebih jelasnya akan dijelaskan tahapan demi tahapan.

\section{a) Uji Kaiser Meyer Olkin (KMO)}

Langkah pertama dari pengolahan analisis faktor adalah menilai variabel yang dianggap layak dan telah diuji validitas untuk dimasukan kedalam analisis selanjutnya. Dari hasil pengelolaan data dengan program SPSS 20 diperoleh output hasil pengolahan yang ditunjukan oleh tabel berikut:
Tabel 10. KMO and Bartlett's Test

\begin{tabular}{lll}
\hline \multicolumn{3}{l}{ Kaiser-Meyer-Olkin } \\
\multicolumn{3}{l}{$\begin{array}{l}\text { Measure of Sampling } \\
\text { Adequacy. }\end{array}$} \\
\multicolumn{3}{c}{$\begin{array}{l}\text { Approx. } \\
\text { Chi- }\end{array}$} \\
Bartlett's Test & Square \\
of Sphericity & Df & 153 \\
& Sig. &, 000 \\
\hline
\end{tabular}

Dari tabel di atas diperoleh angka Keiser Meyer Olkin Measure of Sampling Adequacy (K-M-O MSA) mencapai 0,748 hasil ini termasuk pada hasil yang baik mengingat angka ini sudah di atas 0,5. Nilai Bartlett's Test of Sphericity mempunyai nilai 748,018 dengan signifikansi 0,000 nilai ini berarti bahwa faktor pembentuk variabel sudah baik dan bisa dianalisis lebih lanjut.

\section{b) Proses Ekstraksi}

Proses ekstraksi ini merupakan proses inti dari analisis faktor, Metode pembuatan faktor (ekstraksi variabel) dengan menggunakan Principal Components dan proses rotasi dengan menggunakan metode rotasi Orthogonal yaitu varimax yaitu melakukan ekstraksi terhadap sekumpulan variabel yang telah lolos pada uji validitas sebelumnya, sehingga terbentuk satu atau lebih faktor. Pada proses ekstraksi faktor ini 
penulis menggunakan SPSS 20 dengan metode ekstraksi Principal Componen Analysis (PCA), dengan tingkat Eigenvalues over $=1$ akan yang artinya item dengan angka eigenvalues dibawah ini akan dikeluarkan. Dari ekstraksi ini didapat tabel Communalities, tabel Total Variance Explained, tabel komponen matrix sebagai berikut:

Tabel 11.Communalities

\begin{tabular}{lll}
\hline & Initial & Extraction \\
\hline Saya mengetahui riba (bunga) itu haram & 1,000 &, 773 \\
Investasi bisnis di BNI Syariah baik dan halal & 1,000 &, 629 \\
Tingkat nisbah bagi hasil tidak mempengaruhi nasabah & 1,000 &, 508 \\
Bank dengan label syariah menjadi pertimbangan nasabah & 1,000 &, 652 \\
Promosi menjadi pertimbangan nasabah & 1,000 &, 666 \\
Bank BNI syariah memberikan hadiah yang menarik & 1,000 &, 558 \\
Iklan di media elektronik cukup jelas & 1,000 &, 644 \\
Pelayanan terhadap kritik dan saran ditanggapi dengan baik & 1,000 &, 685 \\
Pelayanan ditangani dengan cepat & 1,000 &, 579 \\
Pelayanan menjadi pertimbangan nasabah & 1,000 &, 648 \\
Karyawan mampu mengatasi complain & 1,000 &, 491 \\
Karyawan mampu menjelaskan produk Bank & 1,000 &, 635 \\
Sikap karyawan ramah & 1,000 &, 592 \\
Penampilan karyawan rapih & 1,000 &, 463 \\
Fasilitas yang tersedia lengkap & 1,000 &, 682 \\
Fasilitas terpelihara dengan baik & 1,000 &, 556 \\
Fasilitas penting bagi nasabah & 1,000 &, 459 \\
Interior gedung & 1,000 &, 429 \\
\hline
\end{tabular}

Sumber : Diolah dari hasil penelitian

Nilai initial merupakan varian variabel sebelum dilakukan ekstrak. Semua nilai initial bernilai 1 , hal ini berarti bahwa sebelum dilakukan ekstraksi variabel tersebut 100\% membentuk faktor tersebut, karena faktor sebelumnya dilakukan ekstraksi adalah sama dengan variabel. Nilai extraction menggambarkan besar persentase varian sesuai variabel yang dapat dijelaskan oleh faktor yang akan terbentuk.

Untuk variabel saya mengetahui riba (bunga) itu haram, mempunyai nilai extraction tertinggi yaitu sebesar 0,773. Hal ini berarti 77,3\% varian variabel saya mengetahui riba (bunga) itu haram, akan terbentuk. Kemudian untuk variabel investasi bisnis di bank BNI Syariah baik dan halal 62,9\%, tingkat nisbah bagi hasil tidak mempengaruhi nasabah 50,8\%, bank dengan label syariah $65,2 \%$, promosi menjadi pertimbangan nasabah 66,6\%, bank BNI syariah memberikan hadiah yang menarik $55,8 \%$ iklan di media elektronik cukup jelas 64,4\%, pelayanan terhadap kritik dan saran ditanggapi dengan baik 68,5\% pelayanan ditangani dengan cepat $57,9 \%$, pelayanan menjadi pertimbangan nasabah 64,8\%, karyawan mampu mengatasi komplain 49,1\%, karyawan mampu menjelaskan produk bank 63,5\%, sikap karyawan ramah 59,2\%, penampilan karyawan rapih 46,3\% 
fasilitas yang tersedia lengkap $68,2 \%$ fasilitas terpelihara dengan baik $55,6 \%$ fasilitas penting bagi nasabah $45,9 \%$ dan variabel interior ruangan mempunyai nilai extraction terendah yaitu 0,429 hal ini berarti $42,9 \%$ varian dari variabel interior gedung nyaman dapat dijelaskan oleh faktor yang akan terbentuk dan variabel semakin besar nilai communalitiesmenunjukan semakin kuat hubungan dengan faktor yang nantinya akan terbentuk.

Dapat dilihat sebenarnya berapakah faktor yang akan terbentuk dari ke 18 variabel tersebut. Tabel dibawah ini akan menjelaskannya, berdasarkan pengolahan data SPSS 20 didapat hasil bahwa 18 variabel yang digunakan dalam penelitian ini akan dikelompokan dalam 6 faktor, sebagai mana yang tertera pada tabel berikut ini:

Tabel 12. Total Vaiance Explained

\begin{tabular}{|c|c|c|c|c|c|c|c|c|c|}
\hline \multicolumn{4}{|c|}{ Component Initial Eigenvalues } & \multicolumn{3}{|c|}{$\begin{array}{l}\text { Extraction Sums of Squared } \\
\text { Loadings }\end{array}$} & \multicolumn{3}{|c|}{$\begin{array}{l}\text { Rotation Sums of Squared } \\
\text { Loadings }\end{array}$} \\
\hline & Total & $\%$ of & $\begin{array}{l}\text { Cumulative } \\
\%\end{array}$ & Total & $\%$ of & $\begin{array}{l}\text { Cumulative } \\
\%\end{array}$ & Total & $\begin{array}{l}\% \text { of } \\
\text { Variance }\end{array}$ & $\begin{array}{l}\text { Cumulative } \\
\%\end{array}$ \\
\hline \multicolumn{4}{|c|}{ Variance } & \multicolumn{3}{|c|}{ Variance } & & & \\
\hline 1 & 4,175 & 23,195 & 23,195 & 4,175 & 23,195 & 23,195 & 2,398 & 13,320 & 13,320 \\
\hline 2 & 1,646 & 9,143 & 32,338 & 1,646 & 9,143 & 32,338 & 2,176 & 12,090 & 25,410 \\
\hline 3 & 1,429 & 7,939 & 40,277 & 1,429 & 7,939 & 40,277 & 1,613 & 8,961 & 34,371 \\
\hline 4 & 1,223 & 6,795 & 47,072 & 1,223 & 6,795 & 47,072 & 1,541 & 8,561 & 42,933 \\
\hline 5 & 1,165 & 6,474 & 53,546 & 1,165 & 6,474 & 53,546 & 1,469 & 8,159 & 51,091 \\
\hline 6 & 1,011 & 5,616 & 59,162 & 1,011 & 5,616 & 59,162 & 1,453 & 8,070 & 59,162 \\
\hline 7 & ,953 & 5,297 & 64,459 & & & & & & \\
\hline 8 & ,926 & 5,147 & 69,606 & & & & & & \\
\hline 9 & ,804 & 4,467 & 74,073 & & & & & & \\
\hline 10 & ,745 & 4,142 & 78,214 & & & & & & \\
\hline 11 & ,660 & 3,664 & 81,878 & & & & & & \\
\hline 12 & ,597 & 3,315 & 85,193 & & & & & & \\
\hline 13 & ,542 & 3,013 & 88,206 & & & & & & \\
\hline 14 & ,522 & 2,899 & 91,105 & & & & & & \\
\hline 15 & ,499 & 2,771 & 93,876 & & & & & & \\
\hline 16 & ,408 & 2,265 & 96,141 & & & & & & \\
\hline 17 & ,367 & 2,041 & 98,182 & & & & & & \\
\hline 18 & ,327 & 1,818 & 100,000 & & & & & & \\
\hline
\end{tabular}

Sumber : Diolah dari hasil penelitian

Berdasarkan output total variance eksplained dapat diketahui bahwa :

a. Faktor pertama yang mempunyai eigenvalue sebesar $=4,175$ varians sebesar $23,195 \%$

b. Faktor kedua mempunyai nilai eigenvalue sebesar $=1.646$, varians sebesar $9,143 \%$

c. Faktor ketiga mempunyai nilai eigenvalue sebesar $=1.429$, varians sebesar 7,939\% d. Faktor keempat mempunyai nilai eigenvalue sebesar $=1.223$, varians sebesar 6,795\%

e. Faktor kelima mempunyai nilai eigenvalue sebesar $=1.165$, varians sebesar $6,474 \%$

f. Faktor keenam mempunyai nilai eigenvalue sebesar $=1.011$, varians sebesar $5,616 \%$

Hasil tersebut menunjukan bahwa faktor 1 mampu 
menjelaskan seluruh varians sebesar 23,195\%, faktor 2 menjelaskan seluruh varians sebesar 9,143\%, faktor 3 menjelaskan seluruh varians sebesar 7,939\%, faktor 4 menjelaskan seluruh varians sebesar 6,795\%, faktor 5 menjelaskan seluruh varians sebesar 6,474\%, dan faktor 6 menjelaskan seluruh varians sebesar 5,616\%. Adapun berdasarkan komulatif seluruh faktor dapat menjelaskan varians sebesar 59,162\%.

Setelah didapat 6 faktor adalah jumlah yang paling optimal, analisis selanjutnya dilakukan pada component matrix yang menunjukan distribusi 18 variabel pada 6 faktor yang terbentuk. Angka-angka yang terdapat pada tabel component matrix merupakan factor of loading yang menunjukan besar kolerasi antara suatu variabel dengan faktor pertama, kedua, ketiga, keempat, kelima dan kelima. Proses penentu variabel asal kedalam faktor dilakukan dengan membandingkan besar kolerasi tiap baris yang didasarkan pada angka mutlak factor of loading yang diberikan setiap variabel terhadap masing-masing faktor.

Tabel 13. Component Matrix ${ }^{a}$

\begin{tabular}{|c|c|c|c|c|c|c|}
\hline & \multicolumn{6}{|c|}{ Component } \\
\hline & 1 & 2 & 3 & 4 & 5 & 6 \\
\hline Saya mengetahui riba (bunga) itu haram & 189 & 149 &,- 407 & 623 & ,304 &,- 263 \\
\hline Investasi bisnis di BNI Syariah baik dan halal &, 506 & 171 &,- 412 & ,367 &,- 038 &,- 194 \\
\hline Tingkat nisbah bagi hasil tidak mempengaruhi nasabah & ,325 & ,407 & 191 & 007 &,- 285 & ,345 \\
\hline Bank dengan label syariah menjadi pertimbangan nasabah &, 539 & 172 &,- 318 &,- 154 & ,218 & 399 \\
\hline Promosi menjadi pertimbangan nasabah & ,320 & ,591 & 036 & 013 & ,377 & ,265 \\
\hline Bank BNI syariah memberikan hadiah yang menarik & ,350 & ,097 &, 578 & 241 & 142 &,- 122 \\
\hline Iklan di media elektronik cukup jelas & ,320 &,- 023 &, 561 &,- 071 & ,450 &,- 136 \\
\hline $\begin{array}{l}\text { Pelayanan terhadap kritik dan saran ditanggapi dengan } \\
\text { baik }\end{array}$ & ,576 & ,288 & 010 &,- 461 & ,138 &,- 196 \\
\hline Pelayanan ditangani dengan cepat & ,470 &,- 560 & 146 &,- 034 & 115 &,- 096 \\
\hline Pelayanan menjadi pertimbangan nasabah & ,397 &,- 321 &,- 040 & 240 & 021 &, 572 \\
\hline Karyawan mampu mengatasi komplain & 662 & 004 & 067 & ,063 & ,207 & 031 \\
\hline Karyawan mampu menjelaskan produk Bank & ,387 & ,338 & ,316 & 126 &,- 501 &,- 057 \\
\hline Sikap karyawan ramah &, 585 & ,128 &,- 182 &,- 233 &,- 358 &,- 135 \\
\hline Penampilan karyawan rapih &, 575 & ,128 &,- 188 &,- 146 &,- 146 &,- 194 \\
\hline Fasilitas yang tersedia lengkap & ,563 &,- 333 &,- 254 &,- 397 & ,156 &,- 089 \\
\hline Fasilitas terpelihara dengan baik & ,625 &,- 365 &,- 005 & 089 &,- 153 &,- 032 \\
\hline Fasilitas penting bagi nasabah &, 547 &,- 067 & 205 & 252 &,- 161 &,- 153 \\
\hline Interior gedung & ,426 &,- 380 & 059 & 135 &,- 167 & ,233 \\
\hline
\end{tabular}

Sumber : Diolah dari hasil penelitian

Tabel di atas digunakan untuk melihat besarnya nilai factor of loading. Setelah diketahui bahwa enam faktor adalah jumlah yang paling optimal, tabel component matrix diatas menunjukkan distribusi ke 18 variabel pada delapan faktor yang terbentuk. Sedangkan angka-angka yang ada pada tabel tersebut adalah factor loadings, yang menunjukkan besarnya korelasi antara suatu variabel dengan faktor 1, faktor 2, faktor 3, faktor 4, faktor 5 dan faktor 6. Selanjutnya dalam proses penentuan masing-masing variabel manakah yang akan masuk kedalam faktor 1 sampai 6 dilakukan dengan melakukan 
perbandingan besarnya korelasi pada setiap variabel.

Korelasi antaravariabel dapat diasumsikan bahwa semakin jauh dibawah 0,5 maka korelasi hubungan antara variabel tersebut semakin lemah, begitupun sebaliknya. Semakin jauh di atas angka 0,5, maka korelasi antara variabel tersebut semakin kuat.

Dalam Tabel component matrix ini, masih ada beberapa variabel yang tidak terlihat perbedaan nyata pada nilai loading factor, sehingga sulit untuk menentukan variabel tersebut termasuk faktor yang mana. Hal ini terlihat dari masih ada nilai loading factor yang dibawah 0,5, yaitu pada variabel pelayanan. Sementara syarat suatu variabel masuk kedalam suatu faktor, nilai loading factor harus di atas 0,5. Untuk melihat perbedaan yang nyata pada nilai loading factor dari setiap variabel, maka harus dilakukan proses rotasi. Rotasi dalam penelitian ini adalah rotasi dengan metode Varimax, yang bertujuan untuk memperbesar nilai loading factor yang dulunya memang sudah besar dan memperkecil nilai loading factor yang dulunya memang sudah kecil, sehingga diperoleh distribusi loading factor yang lebih jelas dan nyata.

Tabel 14. Rotated Component Matrix ${ }^{a}$

\begin{tabular}{lllllll}
\hline & \multicolumn{1}{l}{ Component } & & & \\
\cline { 2 - 7 } & 1 & 2 & 3 & 4 & 5 & 6 \\
\hline Saya mengetahui riba (bunga) itu haram &,- 055 &,- 015 &, 045 &,- 124 &, 090 &, 863 \\
Investasi bisnis di BNI Syariah baik dan halal &, 309 &, 148 &,- 069 &, 165 &, 110 &, 683 \\
Tingkat nisbah bagi hasil tidak mempengaruhi nasabah &, 060 &, 082 &, 008 &, 592 &, 371 &,- 098 \\
Bank dengan label syariah menjadi pertimbangan nasabah &, 355 &, 266 &,- 087 &,- 032 &, 660 &, 100 \\
Promosi menjadi pertimbangan nasabah &, 069 &,- 169 &, 244 &, 149 &, 727 &, 150 \\
Bank BNI syariah memberikan hadiah yang menarik &,- 050 &, 109 &, 673 &, 289 &, 022 &, 084 \\
Iklan di media elektronik cukup jelas &, 088 &, 054 &, 777 &,- 072 &, 113 &,- 106 \\
Pelayanan terhadap kritik dan saran ditanggapi dengan baik &, 710 &,- 110 &, 279 &, 085 &, 285 &,- 042 \\
Pelayanan ditangani dengan cepat &, 277 &, 564 &, 338 &,- 190 &,- 184 &,- 016 \\
Pelayanan menjadi pertimbangan nasabah &,- 117 &, 728 &,- 042 &, 030 &, 316 &, 035 \\
Karyawan mampu mengatasi komplain &, 331 &, 343 &, 363 &, 078 &, 285 &, 212 \\
Karyawan mampu menjelaskan produk bank &, 169 &, 045 &, 145 &, 762 &,- 037 &, 043 \\
Sikap karyawan ramah &, 657 &, 147 &,- 103 &, 349 &, 032 &, 079 \\
Penampilan karyawan rapih &, 602 &, 109 &, 019 &, 207 &, 077 &, 200 \\
Fasilitas yang tersedia lengkap &, 670 &, 363 &, 056 &,- 304 &, 074 &,- 024 \\
Fasilitas terpelihara dengan baik &, 357 &, 602 &, 138 &, 117 &,- 107 &, 150 \\
Fasilitas penting bagi nasabah &, 212 &, 348 &, 318 &, 346 &,- 106 &, 247 \\
Interior gedung &, 084 &, 636 &, 039 &, 123 &,- 016 &, 001 \\
\hline
\end{tabular}

Sumber : Diolah dari hasil penelitian

Setelah dilakukan rotasi, maka dapat dengan mudah menentukan variabel-variabel mana yang akan masuk kelima faktor tersebut. Dari rotated komponen matrix kita melihat bahwa variabel yang termasuk dalam component 1 yaitu variabel Pelayanan terhadap kritik dan saran ditanggapi dengan baik, Fasilitas yang tersedia lengkap, Sikap karyawan ramah dan
Penampilan karyawan rapih. Dengan nilai factor of loading masing-masing variabel sebesar $0,710,0,670,0,657,0,602$. Hal ini berarti, bahwa variabel tersebut mempunyai kolerasi yang tinggi terhadap faktor 1, kemudian untuk component 2 yaitu pelayanan menjadi pertimbangan nasabah, interior gedung nyaman, fasilitas terpelihara dengan baik 
danPelayanan ditangani dengan cepat. Dengan nilai factor of loading masing-masing variabel sebesar $0,728,0,636,0,602$, dan 0,564, kemudian untuk component 3 yaitu iklan di media elektronik cukup jelas dan bank BNI syariah memberikan hadiah yang menarik dengan nilai factor of loading sebesar 0,777 dan 0,673 , kemudian untuk component 4 yaitu karyawan mampu menjelaskan produk bank dan tingkat nisbah bagi hasil tidak mempengaruhi nasabah dengan nilai factor of loading sebesar 0,762 dan 0,592, untuk component 5 yaitu promosi menjadi pertimbangan nasabah dan Bank dengan label syariah menjadi pertimbangan nasabah dengan nilai factor of loading sebesar 0,727 dan 0,660, dan untuk component 6 yaitu saya mengetahui riba (bunga) itu haram dan investasi bisnis di bank BNI Syariah baik dan halal dengan nilai factor of loading sebesar 0,863 dan 0,683 .

Hasil analisis faktor adalah 18 variabel yang diteliti melalui analisis faktor dengan metode ekstraksi principle componen tanalysis yang direduksi menjadi 6 faktor dimana variabel-variabel, yang termasuk dalam faktor 1 pelayanan terhadap kritik dan saran ditanggapi dengan baik, fasilitas yang tersedia lengkap, sikap karyawan ramah dan penampilan karyawan rapih, faktor 2 yaitu pelayanan menjadi pertimbangan nasabah, interior gedung nyaman, pelayanan ditangani dengan cepat dan fasilitas terpelihara dengan baik, faktor 3 yaitu iklan di media elektronik cukup jelas, bank BNI syariah memberikan hadiah yang menarik, faktor 4 yaitu karyawan mampu menjelaskan produk bank, tingkat nisbah bagi hasil tidak mempengaruhi nasabah, faktor 5 yaitu promosi menjadi pertimbangan nasabah, bank dengan label syariah menjadi pertimbangan nasabah, dan untuk faktor 6 yaitu saya mengetahui riba (bunga) itu haram, investasi bisnis di bank BNI Syariah baik dan halal.

Tabel 15. Faktor-faktor yang mempengaruhi nasabah dalam menggunakan produk jasa perbankan syariah

\begin{tabular}{lllll}
\hline Faktor & Variabel asal & Nilai Faktor & Eigenvalue & Varian (\%) \\
Faktor I & Pelayanan & 0,710 & & \\
& Fasilitas & 0,670 & 4,174 & 23,195 \\
& Pelayanan & 0,657 & & \\
Faktor II & Pelayanan & 0,602 & & \\
& Pelayanan & 0,728 & & \\
& Fasilitas & 0,636 & & \\
& Pelayanan & 0,602 & 1,646 & \\
Faktor III & Fasilitas & 0,564 & & \\
& Promosi & 0,777 & \multirow{2}{*}{7,429} & \\
Faktor IV & Promosi & 0.673 & & \\
& Promosi & 0,762 & 1,223 & \\
Faktor V & Agama & 0,592 & & \\
& Promosi & 0,727 & 1,165 & 6,474 \\
Faktor VI & Agama & 0,660 & & \\
& Agama & 0,863 & 1,011 & 5,616 \\
\hline
\end{tabular}

Sumber : Diolah dari hasil penelitian 


\section{KESIMPULAN DAN IMPLIKASI}

Bedasarkan hasil analisis pengolahan data, dan analisis ekonomi, maka kesimpulan yang dapat diambil dari penelitian ini adalah :

1. Karakteristik nasabah BNI syariah cabang Sukabumi mampu memberikan gambaran mengenai alasan mereka memilih diantara faktor fasilitas, agama, pelayanan, dan promosi yang mempengaruhi nasabah dalam menggunakan produk jasa perbankan syariah. Dari 202 responden yang diteliti terhadap lima faktor tersebut memiliki korelasi yang positif antara variabel pelayanan memiliki factor of loading sebesar 0,728, diikuti dengan variabel fasilitas memiliki factor of loading sebesar 0,670, variabel promosi memiliki factor of loading sebesar 0,777, agama memiliki factor of loading sebesar 0,863 .

2. Hasil analisis data yang dilakukan dapat diketahui bahwa dari 4 variabel yang diteliti, variabel agama memilikinilai factor of loading yang cukup kuat dan memiliki korelasi yang positif antara variabel sebesar 0,863 , dan promosi menjadi faktor yang ke dua memiliki factor of loading yang cukup kuat dan memiliki korelasi yang positif antar variabel sebesar 0,777 , pelayanan menjadi faktor yang ke tiga yang memiliki factor of loading yang cukup kuat dan memiliki korelasi yang positif antar variabel sebesar 0,728 , sementara itu faktor fasilitas menjadi faktor yang ke empat yang memiliki factor of loading yang cukup kuat dan memiliki korelasi yang positif antar variabel sebesar 0,670. Ini berarti $\mathrm{H}_{0}$ (Faktor fasilitas, pelayanan, agama, promosi mempengaruhi keputusan nasabah dalam menggunakan produk jasa perbankan syariah) diterima sedangkan $\mathrm{H}_{1}$ (Faktor fasilitas, pelayanan, agama, promosi tidak mempengaruhi keputusan nasabah dalam menggunakan produk jasa perbankan syariah) ditolak. Faktor agama merupakan variable yang paling dominan berpengaruh terhadap nasabah dalam memilih menggunakan produk jasa suatu bank syariah dengan nilai factor of loading yang cukup kuat dan memiliki korelasi yang positif antara variabel sebesar 0,863 .

3. Bagi PT bank BNI Syariah cabang Sukabumi, diharapkan pada waktu yang akan datang terus meningkatkan dan memberikan produk-produk yang sesuai dengan syariah serta lebih meningkatkan promosi untuk mempertahankan dan mendapatkan nasabah yang lebih banyak lagi.

4. Hal terpenting yang tidak boleh dilupakan dalam dunia usaha adalah idealisme produk atau kinerja berdasarkan operasional syari'at Islam yang harus terus dipertahankan karena hal ini yang membedakan antara konvensional dengan syariah.

\section{DAFTAR PUSTAKA}

Alamsyah, Halim. Perkembangan dan Prospek Perbankan Syariah Indonesia: Tantangan Dalam Menyongsong MEA 2015 (http://www.bi.go.id/id/ruan g-media/pidato-dewangubernur/Documents/6bf008 12e40b4d0cb140ea80239c49 66PerkembanganProspekPerb ankanSyariahIndonesiaMEA20 1.pdf 6.39). Diakses pada Tanggal 27 April 2015 jam 19:00 wib

Arthesa, Handiman. 2006. Bank Dan Lembaga Keuangan Bukan Bank. Jakarta: PT. Indeks 
Basuki, Sulistyo. 2006. Metode Penelitian. Jakarta: Wedatama Widya Sastra dan Fakultas Ilmu Pengetahuan Budaya Universitas Indonesia.

Dendawijaya, Lukman. 2001. Manajemen Perbankan. Jakarta : Ghalia Indonesia.

Djumhana, Muhammad. 1996. Hukum Perbankan Di Indonesia. Bandung: PT. Citra Aditya Bakti.

Ghozali, Imam. 2005. Aplikasi Analisis Multivariate Dengan Program SPSS.Semarang : Universitas Diponegoro.

Gitosudarmo, Indriyo. 2000. Manajemen Pemasaran. Yogyakarta: BPFE.

Hasibuan, Malayu. 2001. Manajemen Sumber Daya Manusia: Pengertian Dasar, Pengertian, dan Masalah. Jakarta: PT. Toko Gunung Agung.

Hosen, Nadratuzzaman. 2006. Buku Saku Lembaga Bisnis Syariah. Jakarta: Pusat Komunikasi Ekonomi Syariah.

Husein \& Umar. 2000. Metodologi Penelitian. Jakarta: Gramedia.

Kasmir. 2001. Manajemen Perbankan. Jakarta: PT Raja Grafindo Persada.

Kasmir. 2001. Bank dan Lembaga Keuangan Lainnya.Jakarta: PT Raja Grafindo Persada.

Karim, Adiwarman. 2003. Bank Islam, Analisis Fiqh dan Keuangan. Jakarta: The International Institute of Islamic Thought.

Karim, Adiwarman. 2007. Bank Islam, Analisis Fiqih dan Keuangan.Jakarta: PT Raja Grafindo Persada.

Kasmir. 2002. Bank dan Lembaga Keuangan LainnyaEdisi Revisi.Jakarta: PT. Raja Grafindo Persada.

Kasmir. 2008. Bank dan Lembaga Keuangan Lainnya Edisi Revisi.
Jakarta: PT.Raja Grafindo Persada.

Kotler, Philip. 2000. Manajemen Pemasaran. Jakarta: PT. Prenhalindo.

Kotler \& Keller. 2009. Manajemen Pemasaran, Jakarta: PT. Indeks.

Kuncoro, Mudrajad. 2003. Metode Riset untuk Bisnis dan Ekonomi. Jakarta : Erlangga.

Lapoliwa, Kuswandi. 2000. Akuntansi Perbankan, Akuntansi Transaksi Bank Dalam Valuta Rupiah, Edisi 5. Jakarta: InstitutBankirIndonesia.

Lipis, Allen. 1992. Perbankan Elektronik. Jakarta : Rineka Cipta.

Mowen. 2002. Perilaku Konsumen Edisi 5. Jakarta: Erlangga.

Muhammad. 2008. Manajemen Pembiayaan Mudharabah di Bank Syariah. Jakarta: Rajawali Press.

Riduwan. 2011. Dasar Dasar Statistika. Bandung: Alfabeta.

Sanusi, Anwar. 2003. Metodologi Penelitian Praktis Untuk Ilmu Sosial dan Ekonomi. Malang: Buntara Media.

Schiffman \& Kanuk. 2004. Perilaku Konsumen Edisi 7. Jakarta: PT. Indeks.

Setiadi, Nugroho. 2003. Perilaku Konsumen, Konsep dan Implikasi untuk Strategi dan Penelitian Pemasaran. Jakarta: Kencana.

Stanton, William.1996. Prinsip Pemasaran. Jakarta : Erlangga.

Sudarsono, Heri. 2004. Bank dan Lembaga Keuangan Lainnya. Yogyakarta: Adipura.

Sugiyono. 2003. Metode Penelitian Bisnis. Bandung: Alfabeta.

Suyatno, Thomas. 1999. Kelembagaan Perbankan. Jakarta : PT. Gramedia Pustaka Utama. 
Swastha, Basu. 2000. Manajemen Penjualan. Yogyakarta : BPFE.

Swastha, Basu. 2002. Manajemen Pemasaran. Jakarta: Liberty.

Tjiptono, Fandy. 2005. Pemasaran Jasa. Malang: Bayu Media Publising.

Taswan. 2005. Akuntansi Perbankan Transaksi dalam Valuta Rupiah.Yogyakarta: UPP AMP YKPN.

Trihantana, Rully. 2013. Bahan Ajar Mata Kuliah Perdagangan Internasional. Bogor: Universitas Djuanda.

Yahya, Subchan. 2010. Analisis faktorfaktor yang mempengaruhi keputusan nasabah untuk menggunakan jasa bank syariah(studi kasus PT bank Syariah Mandiri Tbk. Cabang Pembantu Lebak). Skripsi. Jakarta: UIN Syarif Hidayatullah. 